\title{
Fostering online social capital during the COVID-19 pandemic and new normal
}

\author{
Iwan Nugroho \\ Editor in chief, Journal of Socioeconomics and Development, Widyagama University of Malang \\ *Correspondence email: iwanuwg@widyagama.ac.id
}

\section{ARTICLE INFO}

- Editorial

Article History

Received 20 September 2020

Accepted 30 September 2020

Published 31 October 2020

\section{Keywords}

new normal; pandemic; public health; social distancing; social capital

JEL Classification H51; I18; O35

\begin{abstract}
The impact of the COVID-19 pandemic in Indonesia shows a worrying phenomenon. The trend of increasing cases continues, with the number of confirmed cases approaching 4000 cases a day. Efforts to implement social distancing have been carried out in various regions which show a significant number of cases. At present, the Indonesian government has also prepared economic recovery through the new normal concept, by reopening public service activities and business economy while strictly implementing health protocols. This paper tries to provide a conception of online social capital to recommend solving the pandemic problem. Online social capital will generate productivity in people's lives in adherence to health protocols such as handwashing, wearing face masks, and other protective measures attempts. Furthermore, online social capital is expected to have an impact on smoothing the infection curve and stopping the transmission of the virus. This article suggests four steps including managing infodemic and literacy capacity, staying at home and protecting families from the spread of the virus, utilizing digital communication effectively, and preparing emergency response procedures for disaster management.
\end{abstract}

Citation: Nugroho, I. (2020). Fostering online social capital during the COVID-19 pandemic and new normal. Journal of Socioeconomics and Development, 3(2), 74-78. https://doi.org/10.31328/jsed.v3i2.1640

\section{INTRODUCTION}

COVID-19 pandemic is still affecting all over the world. All socio-economic aspects of life are affected by the pandemic and they carry implications for the policies of each country. Bauch \& Galvani (2013) have identified SARS-coronavirus as a dangerous virus, and a vaccine has yet to be found. The pandemic may still be continuing to provide certain threats and pressures that affect the life of every individual (Bard, 2020). Life in various fields has changed markedly. In many ways, it has created a new culture that never existed before.
Indonesian government continues to work on curbing the pandemic by involving other interested parties. The updated data by September 28, 2020 showed a total case of 278,722 infected people, 204,870 recovered patients, 61,379 patients in care and isolation, and 10,472 people died (https://covid19.go.id/peta-sebaran/). The trend of increasing cases is predicted to remain in place, with the confirmed number approaching 4,000 cases a day (Figure 1).

Efforts to implement social distancing have been carried out in many regions which show a significant number of cases. However, there is a lengthy discussion regarding the implications of social 
distancing. Efforts to carry out social distancing need to be done as early as possible so that the spread of the virus stops immediately (Kraemer et al., 2020). Economic activity is also important to sustain people's lives and it is still needed to solve developmental problems in general.

In developing countries, the implications of social distancing are very complex. Von Braun, Zamagni, \& Sorondo (2020) stated that social restrictions are only appropriate for rich people. Rich people can stay at home, wear masks and use personal protective equipment, and can even access technology to work or study from home. Poor people do not have many choices, as they have to work, travel, face health risks, and their children are unable to access online education. Therefore, social distancing cannot last long. Once the infection case curve starts to flatten or decline, social distancing can be reduced (Kissler, Tedijanto, Lipsitch, \& Grad, 2020).

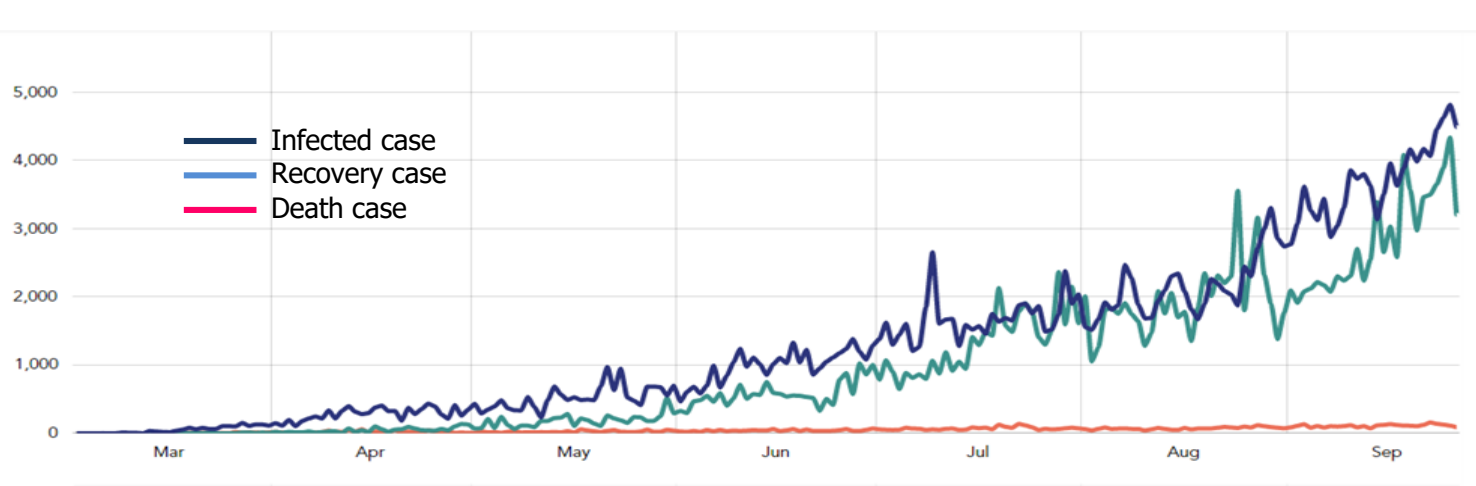

Figure 1. Daily number of cases of infection, recovery, and death during the pandemic (Source: https://covid19.go.id/peta-sebaran)

The Indonesian government, as well as that of other countries, have been preparing to carry out economic recovery through the new normal concept. The new normal concept is reopening public service activities and the business economy while strictly implementing health protocols, for example keeping physical distance, wearing masks, washing hands, and caring for health; this is supported by health care handling standard procedures.

However, entering the new normal state, an unanswered question remains to exist. On the one hand, the curve for the number of infected cases is still showing resurgence, and at the same time, the health protocol has not been implemented in a disciplined manner by the community. As previously stated (von Braun et al., 2020), many people have not complied with social distancing and health protocols because they have to meet their economic needs.

\section{NEW CULTURE}

The impact of the COVID-19 pandemic needs to be addressed positively by developing social potentials while adhering to health protocols. The COVID-19 pandemic opens up insights on the need for a multidisciplinary approach to the prevention of virus spreading (Prather, Wang, \& Schooley, 2020). Hodges \& Jackson (2020) stated that it is time to rethink cultural institutions which can provide resilience for the survival of life, and to revitalize the economy. In a life called new normal, everyone needs to build a new culture by implementing new views, lifestyles, and economic behavior. Society needs to show social responsibility, to share more, to care more, to be more inclusive, and to comply with health protocols (von Braun et al., 2020; Walker et al., 2020).

Meanwhile, there have also been positive reactions in the community regarding the COVID-19 pandemic. As Hodges \& Jackson (2020) suggested, an institution or a culture can react positively and be able to provide resilience during pandemic periods. The COVID-19 pandemic in Indonesia has raised new terms related to social distancing, work from home, or self-isolation, or lockdown. Society, business life, and government responds to this with their respective responses. At the same time, the flow of 
information is so fast, that it requires the ability of everyone to filter information from hoaxes (Djalante et al., 2020). This is a crucial question in facing the new normal period.

\section{SOCIAL CAPITAL}

Community resilience in anticipating a pandemic can be approached through the concept of social capacity and social capital. Social capacity is an instrument that is able to organize complexity, through regulation, cooperation, and empowerment of the parties involved. Building social capacity is an important component in sustainable resource management (Schwaninger, 2018).

Social capital is a concept that refers to social ties (Putnam, 2001) to produce empowerment and community participation accompanied by commitment and optimal life performance (DeFilippis, 2001; Fukuyama, 2000). Social capital is the foundation of a society that can solve problems and it is a strength for society to be independent and to defend themselves. The more social capital you have, the stronger the social capacity of the community will be (Amornsiriphong, Piemyat, \& Charoenrat, 2012). Social capital as a stock provides a medium for the development of social capacity. Social capacity provides direction for the management planning of a sustainable resource.

The implementation of social capital and social capacity to respond to pandemics has emerged from many studies. People have the initiative to use their abilities to help government efforts to implement social distancing programs or other activities. In Korea, women's groups volunteer to find, report, and monitor suspected people or COVID-19 patients. They also spray disinfectants and help make masks. In China, people monitor and prohibit the arrival of guests. Countries such as Singapore, South Korea, and China have aggressively built pandemic prevention monitoring networks through the use of big data technology, artificial intelligence, openscience, and citizen-data (Shaw, Kim, \& Hua, 2020).

In Indonesia, the response of the government and society to the pandemic is a little late. Wild information and hoaxes about the pandemic have even dominated various social media platforms, causing social panic and unrest. However, this was quickly understood as more cases of infection emerged and the death toll started. The community then shows responses such as social assistance for infected families, isolating newly arrived families, limiting guest arrivals, activating local self-help security posts, and other social solidarity activities (Djalante et al., 2020). At the same time, the economic activity gives rise to a new phenomenon, namely the emergence of online transactions or direct selling from producers to consumers without going through the market due to the circumstances of social distancing.

\section{FOSTERING ONLINE SOCIAL CAPITAL}

The social capital concept as stated (Fukuyama, 2000; Putnam, 2001) works in normal conditions, where social ties and empowerment operate without the constraints of physical distance. In such, life is still running normally using online and offline communication. In the current pandemic and new normal conditions, the social capital finds challenges that previously did not exist. Therefore, social capital must be able to work in a completely online condition, while at the same time is encouraged to reduce the virus transmission (Pitas \& Ehmer, 2020).

Online social capital becomes relevant in the case of Indonesia, where there is still a lack of adherence to health protocols in the community. Indeed, online social capital can also safeguard people's lives to produce productivity in health protocol framework such as handwashing, wearing face masks, and other protective measures attempts. Online social capital is expected to have a positive impact on the sloping curve of the infection and it will immediately decline as expected in the new normal condition. The recommendations related to fostering online social capital are described below.

First, infodemic management and literacy capacity meet the quality of knowledge. Infodemic is abundant information, both online and offline. In Indonesia, the infodemic initially spread sporadically resulting in mis- and disinformation. This information can harm people's physical and mental health, increasing stigmatization, and leads to poor adherence, thereby reducing the effectiveness of curbing the pandemic (WHO, 2020). Infodemiology is recognized by $\mathrm{WHO}$ as an important emerging scientific field and a critical area of practice during a pandemic. Infodemic management requires an aspect of monitoring information, containing scientific 
literacy capacity, encouraging quality for information review, and reducing distortion (Eysenbach, 2020).

Second, in the pandemic periods, social ties should be increasingly strengthened among individuals, communities, and government agencies to form a stock of social capital. Social capital, in all its forms, is emphasized towards increasing adherence to health protocols and other protective behaviors. The ties in the family must be strengthened to protect the people in the house from the virus transmission (Bian, Miao, Lu, Ma, \& Guo, 2020). Staying at home is a more effective protective behavior than just wearing a mask or washing hands (Yan, Bayham, Fenichel, \& Richter, 2020). Trust in the government is enhanced through the attitude of everyone's compliance with public health indicators, with strengthening collective action to stop the virus spreading (Pitas \& Ehmer, 2020).

Third, online social capital inevitably has to rely on digital mediated communication tools. Social communication through social media plays a major role in generating social capital during the current pandemic. The dissemination of factual information is expected to support productive life activities during the pandemic. Today, life at work, school, and public activities has shifted to remote connections. The digital telecommunication infrastructure is strengthened and supported by subsidized cellular data by the government. Online social capital further involves financing a significant amount of the government budget, specifically to support online student learning for poor families.

Fourth, the pandemic and the impact of COVID19 have taught many things about the importance of social capital in disaster management works. The social capital of COVID-19 is a key consideration in disaster response measures. Humans do not want disasters to occur, but an alert attitude through social capital can provide valuable messages to prepare for unexpected disasters in the future. Indonesia is known to have the potential for major natural disasters, such as volcanic eruptions, earthquakes, tsunamis, floods, or landslides that evenly occur in all regions. A more thorough understanding of effective strategies for building and maintaining social capital during periods of social distancing using digital communication will be a valuable tool in future crises (Pitas \& Ehmer, 2020).

\section{REFERENCES}

Amornsiriphong, S., Piemyat, S., \& Charoenrat, O. (2012). Social capital: foundation to strengthen the sufficiency economy communities. In Procedia Engineering (Vol. 32, pp. 1147-1151). Elsevier Ltd.

https://doi.org/10.1016/j.proeng.2012.02.069

Bard, T. R. (2020). COVID-19 and a new normal? Journal of Pastoral Care \& Counseling, 74(2), 8181. https://doi.org/10.1177/1542305020926831

Bauch, C. T., \& Galvani, A. P. (2013). Social factors in epidemiology. Science, 342(6154), 47-49. https://doi.org/10.1126/science.1244492

Bian, Y., Miao, X., Lu, X., Ma, X., \& Guo, X. (2020). The emergence of a COVID-19 related social capital: the case of China. International Journal of Sociology. 50(5), 419-433. https://doi.org/10.1080/00207659.2020.1802141

DeFilippis, J. (2001). The myth of social capital in community development. Housing Policy Debate, 12(4), 781-806. https://doi.org/10.1080/10511482.2001.9521429

Djalante, R., Lassa, J., Setiamarga, D., Sudjatma, A., Indrawan, M., Haryanto, B., ... Warsilah, $\mathrm{H}$. (2020). Review and analysis of current responses to COVID-19 in Indonesia: Period of January to March 2020. Progress in Disaster Science, 6(April), 100091. https://doi.org/10.1016/j.pdisas.2020.100091

Eysenbach, G. (2020). How to fight an infodemic: The four pillars of infodemic management. Journal of Medical Internet Research, 22(6). https://doi.org/10.2196/21820

Fukuyama, F. (2000). Social Capital and Civil Society (Working Papers). Washington, D.C., Amerika: International Monetary Fund (IMF). https://doi.org/10.5089/9781451849585.001

Hodges, K., \& Jackson, J. (2020). Pandemics and the global environment. Science Advances, 6(28), eabd1325.

https://doi.org/10.1126/sciadv.abd1325

Kissler, S. M., Tedijanto, C., Lipsitch, M., \& Grad, Y. (2020). Social distancing strategies for curbing the COVID-19 epidemic. MedRxiv, 2020.03.22.20041079. https://doi.org/10.1101/2020.03.22.20041079

Kraemer, M. U. G., Yang, C. H., Gutierrez, B., Wu, C. H., Klein, B., Pigott, D. M., ... Scarpino, S. V. (2020). The effect of human mobility and control measures on the COVID-19 epidemic in China. 
Science, 368(6490), 493-497. https://doi.org/10.1126/science.abb4218

Pitas, N., \& Ehmer, C. (2020). Social capital in the response to COVID-19. American Journal of Health Promotion. 34(8), 942-944. https://doi.org/10.1177/0890117120924531

Prather, K. A., Wang, C. C., \& Schooley, R. T. (2020). Reducing transmission of SARS-CoV-2. Science, 368(6498), https://doi.org/10.1126/science.abc6197

Putnam, R. (2001). Social capital: Measurement and consequences. Canadian Journal of Policy Research, 2(1), 41-51. https://doi.org/10.1017/S1474746403001052

Schwaninger, M. (2018). Systemic design for sustainability. Sustainability Science, 13(5), 12251234. https://doi.org/10.1007/s11625-018-05385

Shaw, R., Kim, Y., \& Hua, J. (2020). Governance, technology and citizen behavior in pandemic: lessons from COVID-19 in East Asia. Progress in Disaster Science, 6(April), 100090. https://doi.org/https://doi.org/10.1016/j.pdisas.2 020.100090 von Braun, J., Zamagni, S., \& Sorondo, M. S. (2020). The moment to see the poor. Science, 368(6488), 214-214. https://doi.org/10.1126/science.abc2255

Walker, P. G. T., Whittaker, C., Watson, O. J., Baguelin, M., Winskill, P., Hamlet, A., ... Ghani, A. C. (2020). The impact of COVID-19 and strategies for mitigation and suppression in low- and middle-income countries. Science, 369(6502), 413-422. ttps://doi.org/10.1126/science.abc0035

WHO. (2020). Managing the COVID-19 infodemic: Promoting healthy behaviours and mitigating the harm from misinformation and disinformation. https://www.who.int/news-room/detail/23-092020-managing-the-covid-19-infodemicpromoting-healthy-behaviours-and-mitigating-theharm-from-misinformation-and-disinformation

Yan, Y., Bayham, J., Fenichel, E. P., \& Richter, A. (2020). Do face masks create a false sense of security? a COVID-19 dilemma. MedRxiv, 2020.05.23.20111302.

https://doi.org/10.1101/2020.05.23.20111302 